hands, had been cast on one side, reduced to fragments, and finally buried in the concrete foundation of the new sewer, no one supposing that the discovery represented anything more than some modern interment.

My friend had, however, seen onc of the skeletons complete and in situ, extended at full length, face downwards, in the clay, while I succeeded in gathering a basketful of bones, including fragments of four left-hand femora, thus, probably, attesting the presence of more individuals than the number to which the workmen deposed.

Some of these bones I extracted from the clay itself, the remainder being found among the excavators' ejecta. Almost all of them are broken and have their cavities, even the spongy tissues and diploë of the cranium, completely filled with the clay in which they were discovered. They are easily broken into fragments by hand, have little organic matter remaining in them, and a few exhibit indications of having been gnawed by animals.

The clay-bed itself showed no signs of disturbance, such as would indicate a burial. On the contrary, it was evident that the bones had been quictly covered with river deposits as they lay, and, although near each other, the skeletons did not occupy a common resting-place.

The remains occurred at a depth of 5 feet 6 inches below the surface, 36 feet above Ordnance Datum, and 3 feet above the highest known modern flood-line, given on the authority of $\mathrm{Mr}$. Martin, engineer to the Severn Navigation Commissioners.

It is clear, therefore, that the clay-bed in question must have been deposited at a time when the River. Severn ran, and its flood-loams were laid down, at levels higher by many feet than those of the present day, or, in other words, at some time antecedent to the historic period, during which there is no reason to suppose that our rivers ever met the sea except at existing horizons.

Holmwood, Putney Hill, November 22

\section{Fly-Maggots Feeding on Caterpillars}

AFTER Mr. McLachlan's remarks in NATURE for November 20 (p. 54), on Dr. Bonavia's rote upon the above subject, it is hardly necessary to say that your correspondent, F. N. Pierce (November 27, p. 82) is undoubtedly mistaken in saying that he has bred the house-fly, Musca domestica, from Lepidopterous larvæ. If he has really bred Musca domestica, it is a new fact, and I should be very glad to see a specimen. I have had some considerable experience in breeding Lepidoptera, and have frequently bred out Diptcrous parasites; these have invariably been Tachinids, mostly of the genus Exorista. To the ordinary observer they very closely resemble Musca domestica, but the same observer would very probably call all the various species of Musca, Anthomyia, Homalomyia, Stomoxys, \&c., which - frequently occur in houses, "house-flies." The general appearance of many of these genera is very much the same, and the term "house-fly" is such a vague one that I remember a good microscopist once showed me a slide labelled "rpper and lower wing of house-fly"! some Hymenopteron caught on a window apparently furnishing the materials.

The Diptera are unfortunately much neglected in this country, and many groups are very little known. This is especially the case with the Tachinince, and Lepidopterists who breed them would benefit science by pinning the spccimens and sending them to one or other of the few students of this order of insects.

4, East Street, Lewes, November 29 J. H. A. JENnER

YouR correspondent, Mr. F. N. Pierce, in NATURE for November 27 (p. 82) merely continues the error suggested by Dr. Bonavia's note on this subject. It is not the larvæ of the housefly (Musca dontstica) that he has found as parasites on his butterfly and moth caterpillars, but the larvæ of a Tachina, a Dipterous genus of the Muscidke, too well known among even mere collectors, I should have thought, for such a mistakc to be made. There is of course a superficial resemblance.

M. E. S.

\section{The Forbes Memorial}

MAY I make use of your widely circulated pages to say that I purpose in a few days to send to press a list of the subscribers to the Forbes Memorial, to be bound up with the issue of the zoological memoirs of our lamented friend; the Memorial
Volume is now nearly ready, and I shall be glad to hear from any of the friends of Mr. W. A. Forbes who have not already communicated with me on the subject. May I add that it was agreed by the Committee that subscribers should receive a copy of the volume for every guinea subscribed.

5, Radnor Place, Gloucester Square, W.

F. JEFFREY RîI

\section{THOMAS WRIGHT, M.I., F.R.S}

$\mathrm{T}$ is perhaps hardly sufficiently recognised how much the progress of science has been helped by the leisurehour occupations of busy professional men. No branch of science has profited more from this source than geology, and no calling has furnished so many helpful labourers as medicine. The carcer of Dr. Wright, whose recent death is so sincerely regretted, supplies one of the most notable examples of a life apparently absorbed in the laborious duties of a medical practitioner, yet wherein time was found for the pursuit of a long series of original and valuable researches in palrontology. To those who knew him only as a doctor, it might well seem that his whole time and thought were given to the duties of his medical practice. Those, on the other hand, who met him as a geologist and palæontologist could hardly realise that he had any other occupation than the study of the fossils which he treasured and described with such enthusiasm.

Dr. Wright was born in Paisley in 1809. Having a near relative engaged in the practice of medicine, he chose the same profession for himself, and received the earlier part of his education at Glasgow. Before he had completed his studies, he was induced to quit medicine and take part in the development of the manufacturing arts, then making rapid strides in Scotland. But finding the change unsuited for his temperament he turned back with a sense of relief to the profession he had abandoned, resumed his medical studies in Dublin, and finally graduated in 1846 . Soon thereafter, circumstances led him to settle in Cheltenham, where he has since spent the whole of his long and honoured life. His devotion to the healing art, and his bent towards a scientific treatment of his subject, were soon recognised, and he became successively attached to the Dispensary and General Hospital, and finally Medical Officer of Health for Cheltenham and surrounding districts. $\mathrm{He}$ was twice married, and leaves a son and two daughters by the second marriage.

In the early days of his career Dr. Wright manifested his love for scientific investigation. While still a student in Dublin he devoted himself with ardour to the study of human anatomy, and especially to the application of microscopic research in that department of inquiry. His eyesight, however, not proving strong enough to bear the strain of microscopic work, he finally exchanged that pursuit for the cultivation of palacontology, which from the position of Cheltenham in the midst of richly fossiliferous rocks, lay temptingly open to him. Ranging over the abundant organic remains of the Lias and Oolites of his neighbourhood, he chose the Echinoderms as his special subject, and began to publish the results of his observations. His early papers gained for him the frienclship and co-operation of Edward Forbes. It was arranged that the two naturalists should conjointly describe the Echinoderms of the British Secondary formations, Forbes taking the Cretaceous, and Wright the Jurassic forms. The former did not live to carry out his part of the programmc, which was accordingly completed by his colleague. The monographs on the Secondary Echinoderms were published by the Palæontographical Society, and form an enduring inonument of Dr. Wright's patient and minute research. But while engaged in these investigations, he did not neglect other departments of Jurassic palæontology. In particular, he devoted himself with 
unwearied industry to the collection and comparison of the Cephalopods of the Lias, and at length, after some forty years of preparation, began his great monograph on "The Lias Ammonites," a work of much research, of which the concluding part is about to be issued, and which forms an enduring landmark in the history of English palæontology. In the course of the inquiries rendered requisite for this exhaustive treatise, he not only made himself acquainted with the fossil localities and public and private collections in this country, but paid visits to many parts of the Continent to study the contents of foreign museums and to confer with his fellowlabourers in the same field scattered over France, Switzerland, and Germany. $\mathrm{He}$ was engaged, at the time of his death, upon a monograph of British Cretaceous Starfishes, which he had nearly completed.

The value of his scientific work has been fully recognised by his contemporaries. He was early elected as a Fellow of the Royal Society of Edinburgh. Subsequently he joined the Geological Society of London, and from that body eventually received its highest honour-the Wollaston Medal. In 1879 he was elected into the Royal Society. He was President of the Geological Section of the British Association at the Bristol meeting in 1875 . His published papers and memoirs are numerous, but the largest and most important are his monographs in the publications of the Palacontographical Society.

It was not alone by original research that $\mathrm{Dr}$. Wright strove to foster the progress of his favourite science. As one of the fathers of the Cotteswold Field Club, as President of the Literary and Philosophical Association of Cheltenham, as a frequent lecturer on scientific topics not only in Cheltenham, but in Bristol, Bath, Worcester, and other towns; and generally by the enthusiasm with which, amid all the obstacles of his busy professional life, he contrived to find leisure for the cultivation of science, he was unqucstionably one of the living forces that stimulated the growth of science all over the West of England. His death is therefore a serious deprivation, and will be mourned by all in that region to whom scientific progress is dear.

To a narrower but still a wide circle his removal from among us is the loss of a leal-hearted friend. Those who were thus privileged will cherish the memory of that cheery face with the bright twinkle of eyes that were as brimful at one time of merriment as, at another, they were suffused with sympathy; the joyous laughter that rang out clear and strong from a heart in which there was no guile; the earnest brow and hand upturned behind the ear as the talk went on over his favourite pursuits ; the bursts of enthusiasm as some new fact or novel deduction dawned on him, and the play of humour that was ever ready to break out like a beam of summer sunshine. Dr. Wright made his final expedition in August last ycar, when he joined the writer of these lines in the Island of Arran. Already the symptoms of his fatal malady had shown themselves, and he knew what they foreboded. But he carried with him nevertheless his characteristic sumniness of nature. Seated on the bare mountain-side with the purple heather and vellowed bracken around him, the sea in front, and his own native Renfrewshire hills in the blue distance, he became almost a boy again as he told his reminiscences of old times and watched the sports of children among the gray boulders. Ripe in honours as in years, it seemed as if he had come back to his early northern air to drink it once more, and review his past before he should quit us for ever. $\mathrm{He}$ would saunter for hours in the quiet glen, with no companion but his own thoughts and the sights and sounds of Nature, which were an ever-gushing fountain of pleasure to him. Cherished is every memory of him, but most of all those parting days spent with him at the foot of the mountains and by the shore of the restless sea.

\section{ROBERT A. C. GODWIN-AUSTEN, F.R.S.}

$\mathrm{I} N$ many respects $\mathrm{Mr}$. Godwin-Austen stood out apart from his fellow-geologists in this country. He wrote comparatively little, but what he did write was always weighty and full of suggestiveness. Instead of loading the literature of science with a pile of little papers, each containing some trifling addition or supposed addition to the sum of knowledge, or some criticism well- or illfounded of the work of others, he allowed his ideas to maturc, and published them from time to time in luminous essays which many years afterwards may be read over again with profit as well as pleasure. $\mathrm{He}$ began to write about half a century ago, his earliest papers being devoted to the geological features of Devonshire, of which, at that time, very little was known. By degrees he extended the area of his observations eastwards into the south-eastern counties. His essays "On the Valley of the English Channel" (I850), and "On the Superficial Accumulations of the Coasts of the English Channel, and the changes which they indicate" (185I), were among the most thoughtful contributions that had ever been made to the elucidation of the existing outlines of sea and land. This department of inquiry was one that peculiarly fascinated him. Hence, when his friend Edward Forbes died and left his "Natural History of the European Seas" only half completed, he himself chivalrously finished it, and supplied some chapters which only an accomplished and far-sighted geologist could have written. His various papers on drift-gravels, on boulders in the Chalk, and other superficial phenomena, are all marked by the same grasp and breadth of treatment.

But perhaps the paper which has chiefly contributed to give Mr. Godwin-Austen his ascendency among English geologists and to make his name known beyond geologica! circles is his now well-known essay "On the Possible Extension of the Coal-Measures beneath the South-Eastern Part of England " (1855). In this remarkable memoir he brings to bear his detailed knowledge of the rocks of the south-west of England, the north of France, and the adjoining tracts of Belgium. He marshals all his facts in such a way as to enable us, as it were, to strip off the thick cover of Mesozoic formations and trace the deep-seated connection of the Palæozoic area of Southern England and the Continent. At the time when he wrote, nothing was actually known of the subject, but he predicted that a submerged Palieozoic ridge would be found extending from the south-west of England into France and Belgium. The results of the deep borings of recent years have fully verificd this prediction.

Mr. Godwin-Austen, in his prime, was a frequent speaker at the meetings of the Geological Society, where his keen penetrative criticism and caustic sarcasm formed a prominent and valuable feature in the debates. Some of his most suggestive and pregnant views of geological questions were thrown off in the course of these debates, and were never otherwise published by him. He never courted publicity, but rather shrank from it as an incumbrance under which he would not willingly be fettered. For many years past he has lived as a retired country squire at his beautiful residence near Guildford, taking full interest in the progress of science, and glad to see his fellow-workers in geology under his roof, but seldom venturing into the turmoil of town and the disputatious atmosphere of learned societies. It is some consolation to geologists, who mourn the quenching of one of their luminaries, that his place is taken by a son who, by scientific labours in India and in this country, has proved himself a worthy successor.

\section{CHARLES CLOUSTON}

THE Rev. Chas. Clouston, LL.D., of Sandwick Manse, near Stromness, who died on the roth ult. at the very advanced age of eighty-four years, was a man who 